\title{
TIDAL PATTERNS AND RESOURCE USE IN THE MUSI-BANYUASIN COASTAL ZONE OF SUMATRA ${ }^{1)}$
}

\author{
by \\ SAFWAn Hadi ${ }^{2}$, ARTHur J. Hanson ${ }^{2}$, Koesoebiono ${ }^{2}$, MUSREFinah \\ MAHLAN $^{2}$, Mulia Purba ${ }^{2}$, and SAntoso Rahardjo ${ }^{2}$
}

\begin{abstract}
Tidal influence extends $100 \mathrm{~km}$ upriver in the coastal swamplands of Sumatra and Kalimantan. In planning development or resource use, description of local tidal variation is important since tides interact with river flow to zone the land and waters into a series of distinctive environments. The coastal swamps are being opened for rice cultivation with tidally-influenced irrigation and drainage canals. There are also forestry and fishery activities plus major shipping activities in these delta areas. The tidal patterns arc studied in the South Sumatra coastal portion of the Musi and Banyuasin River basins. The tides are mixed, predominantly diurnal with a maximum range of $3.5 \mathrm{~m}$ near the coast. Significant differences in tidal amplitude and phase exist between rivers separated by deltas often less than $10 \mathrm{~km}$ in width. Differences in river water flow atributed to season or basin characteristics influence tidal patterns. On the Musi river the relationship between tidally-influenced resource uses and distance from the sea suggests the greatest variety of activities occurs within the zone of maximum tidal range 0 to $30 \mathrm{~km}$ from the delta fronts. This zone should therefore be considered a region of special ecological concern. A mechanism is needed for coordinated planning of infrastructure changes likely to influence hydrology or resource uses. Predictive models should be developed for measuring the likely impact of such development on coastal hydrology.
\end{abstract}

\section{INTRODUCTION}

Water movement resulting from tidal effects in rivers and estuaries strongly influences the physical and chemical properties of deltaic lands and surrounding waters. Flood tides can cause extensive salt water intrusion and contribute to peak flood conditions. The ebb condition frequently causes navigation difficulties. However, tidal energy can be an environmental component that may be used to man's advantage. Tidal currents help maintaining estuarine productivity (ODUM 1971) and are very significant element in the transport of fish and shrimp larvae to coastal fish ponds in Indonesia (SCHUSTER 1952). Ebb tides are important for drainage of low-lying coastal ricefields in Jawa (ALBINSON 1976).

1 With contributions in earlier drafts by GORDON W. GROVES and SOEMARTONO SOSROMARSONO.

2 Oceanography team, Environmental Research Training Project, Bogor Agricultural University. 


\section{SAFWAN HADI at. al.}

The extensive tidally-influenced lands and estuaries in Indonesia occur along the east coast of Sumatra, southern areas of Kalimantan and Irian Jaya. Tidal influences can extend $100 \mathrm{~km}$ from the sea on the major rivers. The fluctuations in water level, and the associated salt intrusion patterns, impose an ordering on the environment which leads to a wide variety of ecosystem types over small areas. For the most part the lands are covered by brackishwater or freshwater swamp forests. The aquatic habitats range from the species-poor and unproductive blackwater swamps to the estuaries which support many migratory species. The Banjarese, Buginese, and other specialized coastal dwellers are well-adapted to the resource base and derive a living from a combination of forest product harvest, fisheries, and agriculture.

The traditional rice cultivation techniques for the coastal wetlands (VAN WIJK 1951) differ considerably from the irrigated to upland systems typical of Jawa. The fields are cut out from primary swamp forest and are planted either at the beginning of the annual wet season or towards the end, depending on depth of flooding. The farmers depend upon the tidal back-up of river water for irrigation, and on the drop in water level at low tide for drainage of the acid leachate from the organic soils. This system works for distances up to $1 \mathrm{~km}$ from the river bank without extensive canals and for distances of up to $9 \mathrm{~km}$ inland from the river bank if simple drainage canals are dug to the river.

This traditional use of tidal energy has long intrigued planners, who see vast lowland swamps as potential rice land which could be developed at relatively low cost by substituting tidal back-up in large canal networks for the gravity-fed, or pumping systems otherwise required. In 1969 the Ministry of Public Works began a major effort to open tidal irrigation ricefields in Sumatra and Kalimantan (ECAFE 1969). The pilot projects, populated by transmigrants from Jawa, have been located in areas where there are heavy river traffic and possibilities for other activities such as fish culture. Thus the program has to be considered in a broader regional development context. This is essential since the land development will bring about major alterations in what is generally considered to be an ecologically sensitive environment.

In planning this development the need for local description of tides, as a part of an integrated study of hydrological characteristics, should be apparent. There is a good deal of variability in tidal patterns of the offshore waters (WYRTKI 1961) and effects from coastal landform and river-basin-characteristics are likely to be different from place to place. The choice of 
TIDAL PATTERNS AND RESOURCE USE IN THE MUSI - BANYUASIN

location and the kinds of resource uses to be recommended for various sites within the swampland or waters depend on the tidal information.

The present study provides an analysis of tidal information at eight different stations in the 186,000 ha land and water coastal zone influenced by the Musi and Banyuasin rivers (Fig. 1). This study area covers Delta

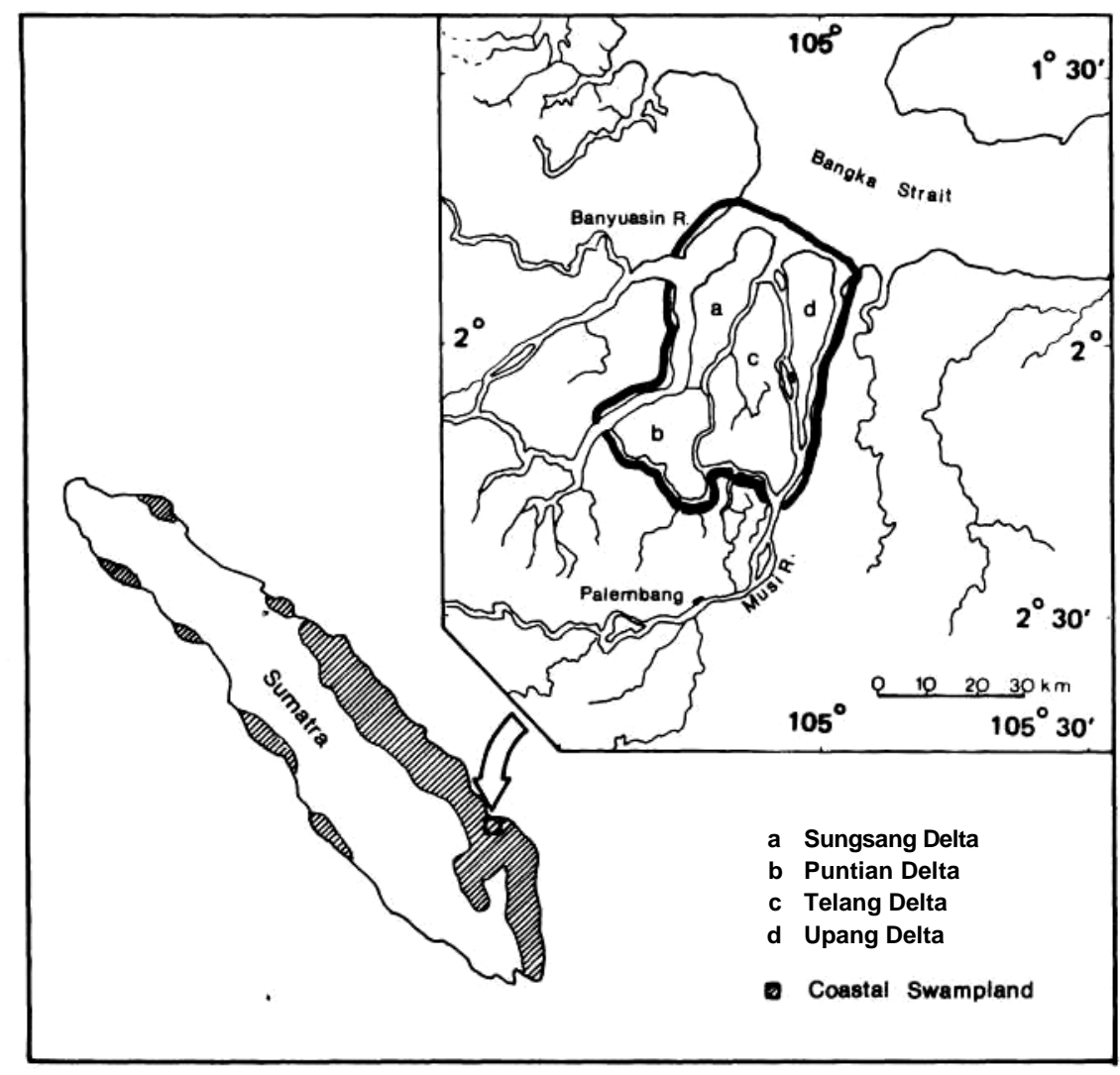

Figure 1. Coastal swampland in Sumatra and Musi-Banyuasin study area.

Upang, one of the pilot projects where canals have already been dug and 1700 transmigrant families settled. Other studies on tides (MINISTRY OF PUBLIC WORKS 1971, SIDJABAT 1971, SUgANDAR 1975, 1TB 1975) have been specifically concerned with the waters of the Musi and Upang rivers in 


\section{SAFWAN HADI at. al}

relation to agricultural canal development. The observations of the present paper arc intended to complement these reports by providing an indication of tidal variability throughout the broader region due to be opened, and of the importance of tides in the maintenance and utilization of natural resources. The study was carried out as part of a broader ecological and resource management survey which may be consulted for details of the MusiBanyuasin (MUBA) coastal area (TEAM SURVHI EKOLOGI 1PB 1975).

\section{METHODS}

\section{Station and gauges}

Water level was measured at eight stations located to provide representative coverage of 3 rivers (Fig. 5), subject to the constraint of accomodation availability. Water level was monitored at hourly intervals for one month (March-April 1975) near the end of the wet season. Information from the 1971 dry season (SIDJABAT 1971) was available from two of the same stations for comparison.

The manual tidal gauge used was a transparent plastic pipe $(6.5 \mathrm{~cm}$ diameter, $5 \mathrm{~m}$ length) affixed to a board marked in $0.5 \mathrm{~cm}$ intervals. In order to minimized disturbances from high frequency waves, the submerged base of the pipe was closed and $0.5 \mathrm{~cm}$ diameter holes drilled into the side of the pipe near the base to allow water entry. Tidal fluctuation relative to mean water surface was measured with this apparatus. The hourly observations were synchronized by daily adjustment of clocks to a Radio Republic Indonesia time signal.

\section{Determination of harmonic constants}

Tides can be represented as:

(1) $\zeta(\vec{x}, t)=\sum_{n} \dot{\zeta}_{n}(\vec{x}) \cos \left(\omega_{n} t \quad \theta_{n}\right)+\zeta^{\prime}(\vec{x}, t)$

where:

$\zeta=$ total tidal fluctuation relative to mean water surface

$\zeta_{n}=$ amplitude of tidal components which only depend on position

$0_{n}=$ phase of tidal components

$\vec{x}=$ position

$\omega_{n}=$ angular frequency of tidal components

$\zeta^{\prime}=$ elevation of water surface caused by other disturbances

$\mathrm{t}=\mathrm{time}$ 


\section{TIDAL PATTERNS AND RESOURCE USE IN THE MUSI - BANYUASIN}

The harmonic constants, that is amplitude and phase, were determined by least square analysis in which the variance $(\mathrm{V})$ of the true tidal elevation should be minimum.

(2) $V=\sum_{m}\left[\hat{\zeta}\left(\vec{x}, t_{m}\right) \quad \sum_{n} \zeta_{n}(\vec{x}) \cos \left(\omega_{n}-\theta_{n}\right)\right]^{2}=$ minimum

$\hat{\zeta}\left(\vec{x}, t_{m}\right)$ is the tidal elevation obtained from observation.

$\mathrm{m}=1,2, \ldots \ldots, \mathrm{M}(\mathrm{M}=$ number of observation points $)$

$\mathrm{n}=1,2, \ldots \ldots, \mathrm{N} \quad \mathrm{N}=$ number of tidal components

introduced in the analysis).

The conditions under which $\mathrm{V}$ is a minimum are:

(3) $\partial$

$$
\begin{aligned}
& \left.\frac{\partial}{\partial \zeta_{j}} \sum_{m} l \hat{\zeta}\left(\vec{x}, t_{m}\right)-\sum_{j} \zeta_{j}(\vec{x}) \cos \left(\omega_{j} t_{m}-\theta_{j}\right)\right]^{2}=0 \\
& \frac{\partial}{\partial \theta_{j}} \sum_{m}\left[\hat{\zeta}\left(\vec{x}, t_{m}\right)-\sum_{j} \zeta_{j}(\vec{x}) \cos \left(\omega_{j} t_{m}-\theta_{j}\right)\right]^{2}=0
\end{aligned}
$$

These are called the normal equations. Amplitude, $\zeta_{\mathrm{n}}(\mathrm{x})$, and phase, $0_{\mathrm{n}}(\mathrm{x})$, were determined by solving the normal equations above.

The least square analysis provides a best fit for the observations but, in general, not the best prediction for times outside the observation period. Further analysis using the more satisfactory Munk-Cartwright convolutionresponse method (MUNK \& CARTWRIGHT 1966) is planned but could not be included in this paper.

The main tidal components introduced in the analysis were the six listed in Table 1. Of these only $\mathrm{M}_{4}$ is a specific shallow water component. It would be desirable to include other shallow water components but this was not possible with the computer facilities available.

Tidal type is determined by the ratio of the amplitude of diurnal component $\mathrm{K}_{1}$ and $\mathrm{O}_{1}$ to the amplitude of semidiurnal components $\mathrm{M}_{2}$ and $\mathrm{S}_{2}$. This ratio is called the Formzahl number $(\mathrm{F})$ :

$$
\mathrm{F}=\frac{\mathrm{K}_{1}+\mathrm{O}_{1}}{\mathrm{M}_{2}+\mathrm{S}_{2}}
$$




\section{SAFWANHADI $a t . A l$.}

According to WYRTKI (1961) Indonesian tides fall into four categories based on the value of $\mathrm{F}$ :

\begin{tabular}{|c|c|c|c|}
\hline \multicolumn{2}{|c|}{ Value } & Type & Example location \\
\hline 00 & 0.25 & semidiurnal & $\begin{array}{l}\text { Malacca Strait north-west of } \\
\text { Bagan Siapi-api. }\end{array}$ \\
\hline 0.25 & 1.5 & $\begin{array}{l}\text { mixed, predominantly } \\
\text { semidiurnal }\end{array}$ & East Indonesian seas. \\
\hline 1.5 & 3.0 & $\begin{array}{l}\text { mixed, predominantly } \\
\text { diurnal }\end{array}$ & Java Sea. \\
\hline & .0 & diurnal & Karimata and Bangka Straits. \\
\hline
\end{tabular}

TABLE I. Important tidal components introduced in the analysis.

\begin{tabular}{llc}
\hline Symbol & \multicolumn{1}{c}{ Component } & $\begin{array}{c}\text { Angular frequency } \\
\text { (degree/hour) }\end{array}$ \\
\hline $\mathrm{M}_{2}$ & Principal lunar semidiurnal & $\mathbf{2 8 . 9 8 4 1 4 2}$ \\
$\mathrm{S}_{2}$ & Principal solar semidiurnal & $\mathbf{3 0 . 0 0 0 0 0 0}$ \\
$\mathrm{N}_{2}$ & Lunar elliptic semidiurnal & 28.4397295 \\
$\mathrm{Ki}$ & Lunisolar declinational diurnal & $\mathbf{1 5 . 0 4 1 0 6 8 6}$ \\
$\mathrm{Oi}$ & Lunar declinational diurnal & 13.9430356 \\
$\mathrm{M}_{4}$ & Biharmonic $\mathrm{M}_{2}$ & 59.9682541 \\
& & \\
\hline
\end{tabular}

\section{RESULTS}

The tidal profile for each station is shown in Figure 2. Tidal fluctuations were computed from the following relationship:

$$
\zeta\left(t_{n}\right)=\cdot \hat{\zeta}\left(t_{n}\right)-\zeta_{0}
$$

where: $\quad \zeta\left(t_{n}\right)=$ tidal fluctuation relative to mean water level

$\hat{\zeta}\left(t_{n}\right)=$ observed water level

$\zeta_{0}=$ mean water level, determined from the equation

$$
\begin{aligned}
\zeta_{0} & =\frac{1}{N} \sum_{n=1}^{N} \hat{\zeta}\left(t_{n}\right) \\
N & =\text { number of observations. }
\end{aligned}
$$


(m) (n) Hours

Figure 2. Tidal profile at 8 stations in the Musi, Telang and Banyuasin River. 
Following substraction of mean water level, the tidal data, standardized to 0.00 W.I.B. ${ }^{1} 20$ March 1975, were analyzed by the methods described previously. The computed harmonic constants are listed in Table II.

TABLE II. Harmonic constants for station I - VIII. Amplitude (A) is given in centimeters and phase $(\mathrm{P})$ in degrees.

\begin{tabular}{|c|c|c|c|c|c|c|c|c|c|}
\hline \multicolumn{10}{|c|}{ STATION } \\
\hline \multicolumn{2}{|c|}{ Component } & I & II & HI & IV & $\mathbf{V}$ & VI & VII & VIII \\
\hline & $\mathbf{A}$ & 39.36 & 48.32 & 39.09 & 36.74 & 30.27 & 33.66 & 36.47 & 34.25 \\
\hline \multirow[t]{2}{*}{$\mathbf{M}_{2}$} & $\mathbf{P}$ & 34.64 & 82.50 & 89.07 & 78.73 & 76.26 & 40.79 & 14.59 & 51.37 \\
\hline & $\mathbf{A}$ & 22.32 & 27.34 & 21.61 & 19.47 & 13.79 & 14.80 & 19.17 & 17.61 \\
\hline \multirow[t]{2}{*}{$\mathbf{S}_{2}$} & $\mathbf{P}$ & 73.53 & -51.25 & -47.21 & -53.13 & -42.90 & 89.89 & 55.24 & -83.21 \\
\hline & $\mathbf{A}$ & 7.13 & 10.08 & 7.55 & 8.19 & 6.06 & 6.27 & 5.99 & 6.58 \\
\hline \multirow[t]{2}{*}{$\mathbf{N}_{2}$} & $\mathbf{P}$ & 74.80 & -66.53 & -74.39 & -71.71 & -64.83 & 81.52 & 62.26 & 89.29 \\
\hline & $\mathbf{A}$ & 78.66 & 86.50 & 74.77 & 72.35 & 61.97 & 66.91 & 72.34 & 71.16 \\
\hline \multirow[t]{2}{*}{$\mathbf{K}_{1}$} & $\mathbf{P}$ & 56.90 & 75.82 & 86.73 & 83.08 & 88.27 & 66.77 & 49.46 & 69.59 \\
\hline & A & 66.38 & 74.24 & 66.77 & 64.20 & 56.03 & 58.32 & 61.19 & 62.22 \\
\hline \multirow[t]{2}{*}{ o, } & $\mathbf{P}$ & 6.96 & 22.47 & 34.70 & 31.23 & 36.38 & 16.63 & -0.34 & 18.66 \\
\hline & $\mathbf{A}$ & 4.55 & 6.58 & 1.89 & 1.28 & 1.48 & 3.71 & 3.84 & 2.68 \\
\hline $\mathbf{M}_{4}$ & $\mathbf{P}$ & 76.63 & -23.80 & 26.26 & 36.66 & -66.93 & 77.14 & 28.50 & 65.96 \\
\hline
\end{tabular}

Tidal type

From an inspection of Figure 2 it is apparent that although the tidal pattern is predominantly diurnal there is a very noticeable influence of semidiurnal components in the periods of minimum tidal range. The Formzahl number of each station as shown in Table III, ranges between the limits (1.5 to 3.0$)$ for which tides can be described as mixed, predominantly diurnal.

TABLE .HI. Formzahl number (F) for stations I - VIII.

\begin{tabular}{cc}
\hline Station & F \\
\hline I & 2.35 \\
II & 2.12 \\
HI & 2.33 \\
IV & 2.43 \\
V & 2.67 \\
VI & 2.58 \\
VII & 2.39 \\
VIII & 2.39 \\
\hline
\end{tabular}

${ }^{1}$ W.I.B. $=$ West Indonesian Standard Time.

116 
TIDAL PATTERNS AND RESOURCE USE IN THE MUSI - BANYUASIN

\section{Phase differences}

As might be expected, phase differences were found between stations. The $\mathrm{P}$ values are shown for the individual tidal components in Table II. Examples of differences between various groups of stations are shown for monthly maximum and minimum tidal ranges in Figures $3 \mathrm{a}$ and $3 \mathrm{~b}$. Crests or troughs can be more than 2 hours out of phase, according to location up the river.

The $\mathrm{K}_{1}$ phase component is useful for investigating time differences of the tidal crest or trough, since the $K_{l}$ amplitude dominates and, because its frequency is relatively separate from the others, interference from other components is small. The time difference between stations can be determined by multiplying the phase differences (in radians) among the stations with a given number $\mathrm{W}$, where:

$$
\mathrm{W}=\frac{\mathrm{T}}{2 \Pi}, \quad \mathrm{T}=\text { period of } \mathrm{K}_{1}
$$

In calculations Sungsang is used as the base point for Musi and Telang river stations and Tg. Genuk for the Banyuasin system. The results are shown in Figure 4. The propagation rate up the Musi river is more constant than in the Telang river, which is a distributary of the Musi with input from several streams. The upriver distances of the tidal crest were computed by 15 minute intervals and are mapped in Figure 5. The differences between channels separated in some areas by deltas of only 5 to $15 \mathrm{~km}$ width is striking. For example the tidal crest arrives 15 to 20 minutes earlier at the Banyuasin entrance of the Sebalik Canal (Terusan Sebalik) which connects the Banyuasin and Telang rivers. The direction and velocity of water flow in this canal are very complex as a result of this phase difference, among other factors.

\section{Frequency distribution of daily tidal range}

At any one station the minimum daily tidal range is, of course, variable over the period of observation. Between stations, river effects such as bottom friction, discharge and channel width would also be expected to influence tidal range. The frequency distribution of the daily tidal range over the one month study period reveals very significant location-dependent differences as shown in Figure 6. The highest range occurs in the broad, but shallow, Banyuasin estuary where a tidal range of 3.0 to $3.5 \mathrm{~m}$ was found on 10 or more days per month. The tidal range of the Telang basin stations does not exceed 2.5 to $3.0 \mathrm{~m}$. This range is also the modal value. In the 


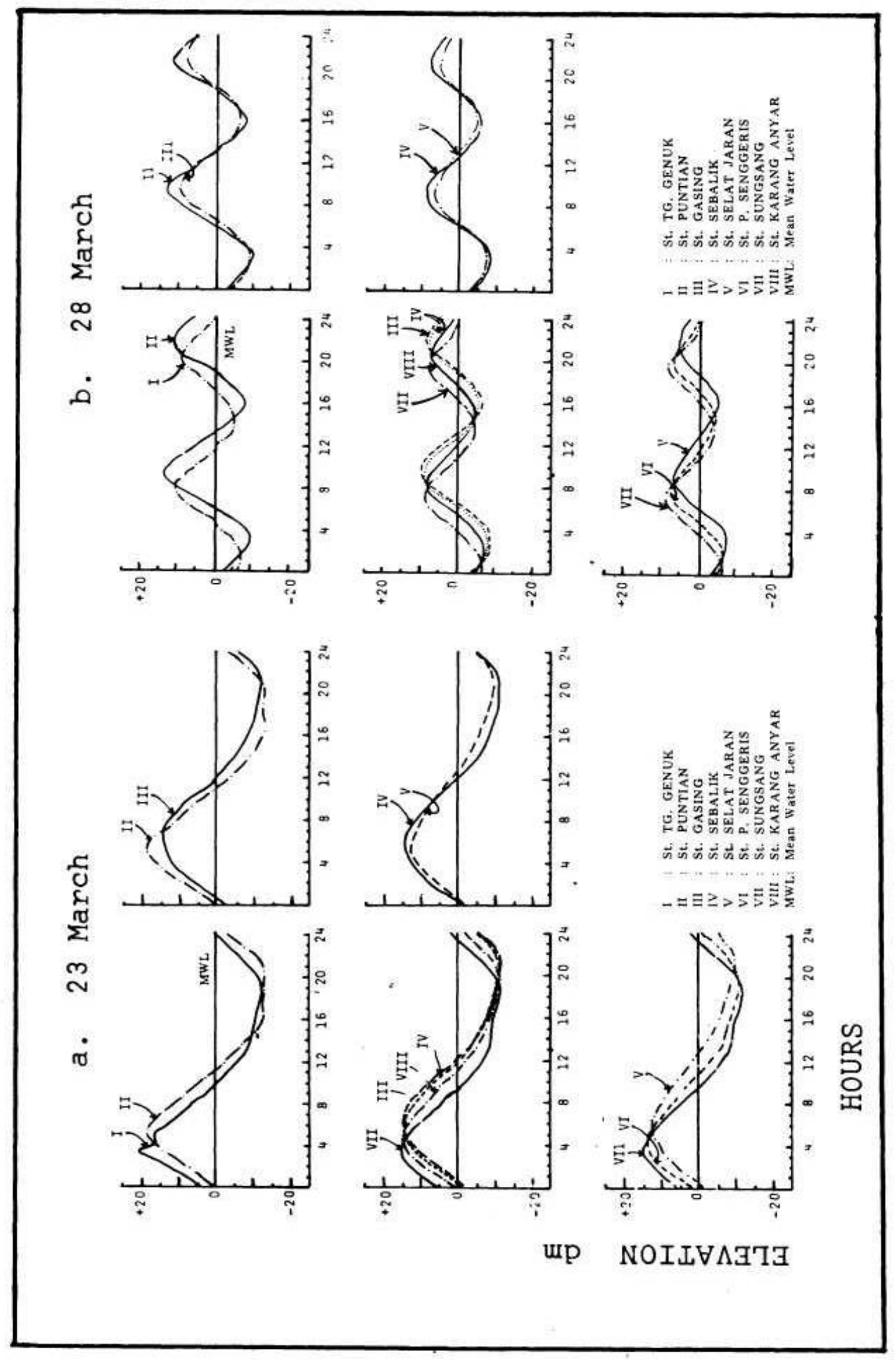

Figure 3. Phase comparisons stations at monthly maximum (a) and minimum (b) tidal ranges. 
TIDAL PATTERNS AND RESOURCE USE IN THEMUSI - BANYUASIN

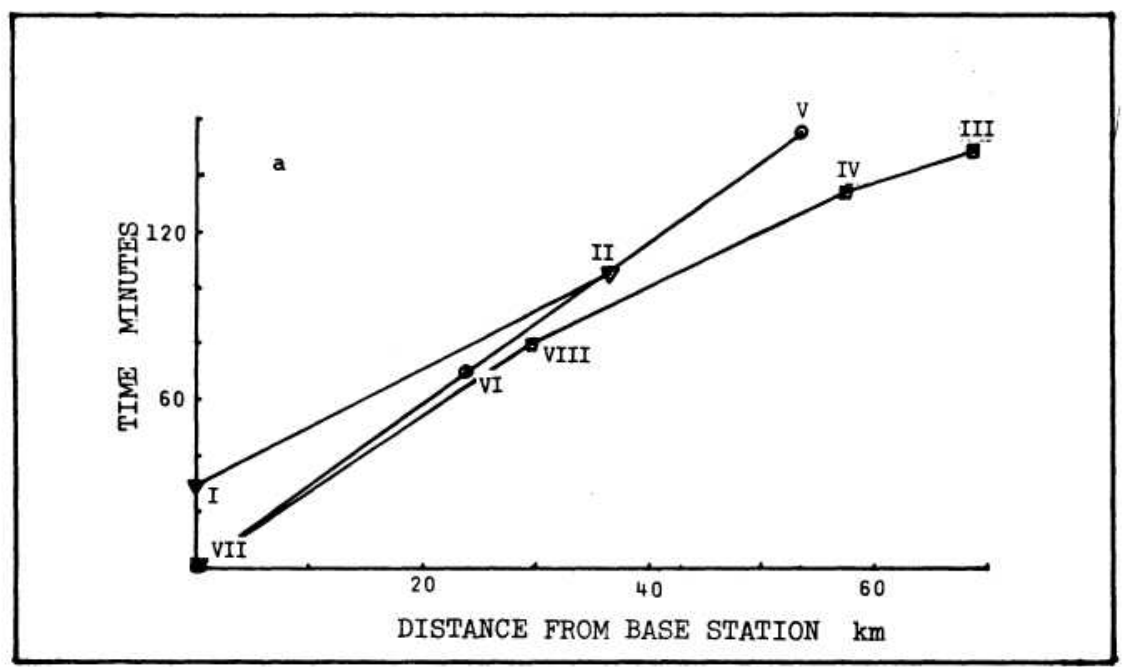

Figure 4. Time of tidal crest or trough as a function of distance upriver in the study area. Zero points are Sungsang for the Musi and Telang, and Tg. Genuk for Banyuasin River.

progression up the Musi river the modal value drops to 2.0 to $2.5 \mathrm{~m}$ and values of 1.0 to $1.5 \mathrm{~m}$ appear at the lower end of the frequency distribution.

\section{Possible seasonal differences}

Unfortunately there are no published data on seasonal variations in river discharge for rivers in the study area. The peak rainfall occurs between December and March while the dry season lasts from June through September (TEAM SURVEI EKOLOGI IPB 1975, MolinA 1974). Monthly wet season rainfall is approximately three times dry season monthly values. The likely difference in discharge might be expected to modify the impact of tides. These possible differences were studied by comparing 1971 dry season and 1975 wet season data from Sungsang and P. Senggeris stations. The 1971 study used identical types of equipment and methods of analysis (SIDJABAT 1 971). Figure 7 shows the tidal profile in 1971 and 1975 at the two stations. The values of the harmonic constants are given in Table IV. A number of differences are apparent from the comparison. The 1971 Formzahl numbers (>3.0) are suggestive of a more diurnal pattern. The amplitude of the $\mathrm{K}_{1}$ component in the 1975 study is smaller, while the semi-diurnal components $\mathrm{M}_{2} . \mathrm{S}_{2}$. and $\mathrm{N}_{2}$ are all larger in amplitude in the wet season study. The dry 


\section{SAFWAN HADI at. al}

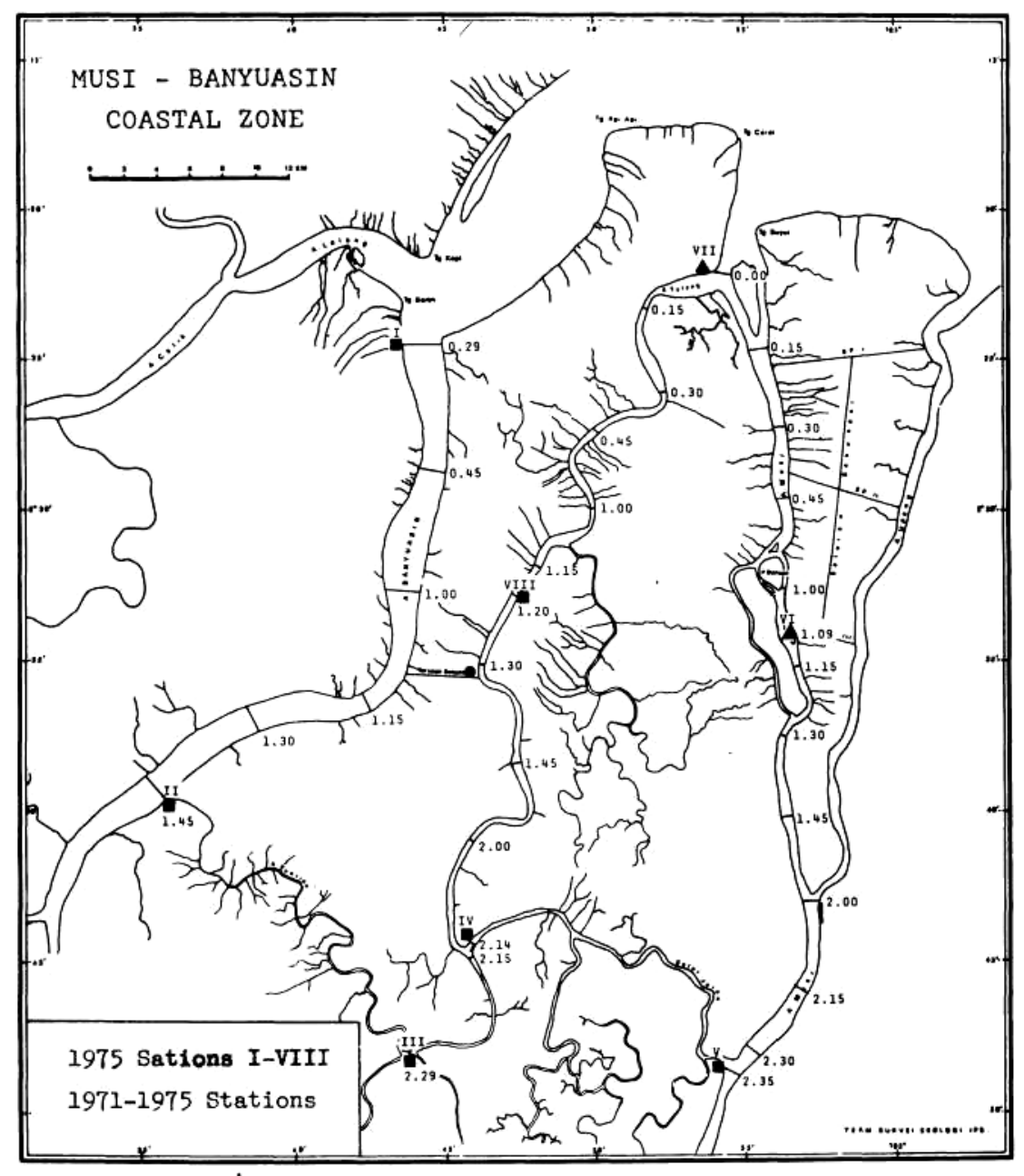

Figure 5. Tidal propagation expressed as movement of the crest or trough at 15 minute intervals. See Figure 3 for names assigned to each station. Location of tidal measurement stations is indicated. 
TIPAL PATTERNS AND RESOURCE USE IN THE MUSI - BANYUASIN

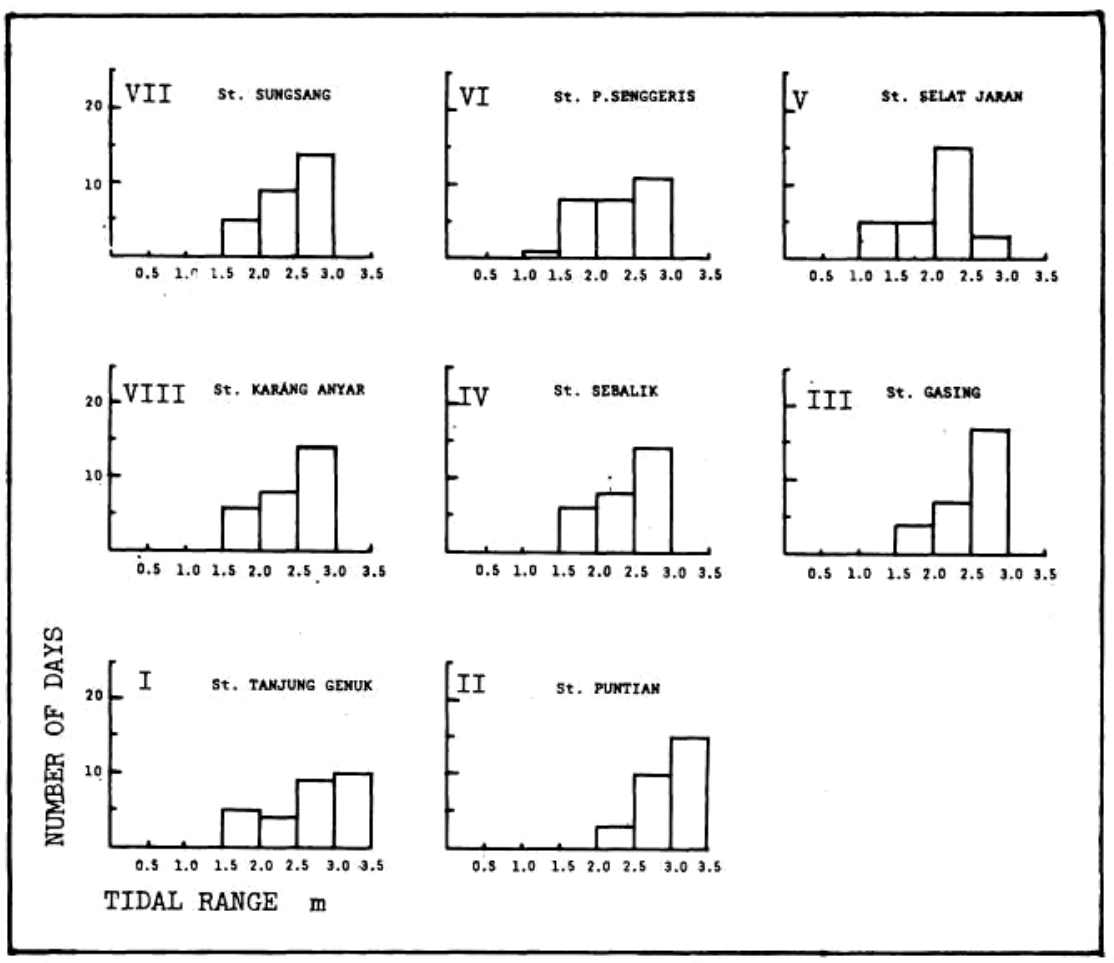

Figure 6. Frequency distribution of daily tidal range over the one month observation period March - April 1975.

TABLE IV. Harmonic constants from Sungsang and Pulau Senggeris for 1971 dry season and 1975 wet season. Amplitude (A) is given in centimeters and phase (P) in degrees.

\begin{tabular}{|c|c|c|c|c|c|}
\hline \multirow{2}{*}{\multicolumn{2}{|c|}{ Component }} & \multicolumn{2}{|c|}{ P. Senggeris } & \multicolumn{2}{|c|}{ Sungsang } \\
\hline & & 1971 & 1975 & 1971 & 1971 \\
\hline \multirow[b]{2}{*}{$\mathrm{M}_{2}$} & $\mathbf{A}$ & 32.63 & 33.66 & 34.004 & 36.47 \\
\hline & $\mathbf{P}$ & -6.10 & 40.79 & -31.31 & 14.59 \\
\hline \multirow{2}{*}{$\mathrm{S}_{2}$} & A & 9.79 & 14.80 & 10.87 & 19.17 \\
\hline & $\mathbf{P}$ & 73.64 & 89.89 & 54.97 & 55.24 \\
\hline \multirow[t]{2}{*}{$\overline{\mathrm{N}_{2}}$} & A & 4.07 & 6.27 & 4.04 & 5.99 \\
\hline & $\mathbf{P}$ & 67.46 & 81.52 & 35.98 & 62.26 \\
\hline \multirow[t]{2}{*}{$\overline{\mathrm{K}_{2}}$} & A & 105.57 & 66.91 & 108.34 & 72.34 \\
\hline & $\mathbf{P}$ & -25.26 & 66.77 & 39.77 & 49.46 \\
\hline \multirow[t]{2}{*}{$\overline{\mathrm{O}_{2}}$} & $\overline{\mathbf{A}}$ & 59.86 & 58.32 & 61.13 & 61.19 \\
\hline & $\mathbf{P}$ & 89.77 & 16.63 & 75.93 & -0.34 \\
\hline \multirow[b]{2}{*}{$\mathrm{M}_{4}$} & $\mathbf{A}$ & 3.47 & 3.71 & 3.00 & 3.84 \\
\hline & $\mathbf{P}$ & 88.00 & 77.14 & -63.07 & 28.50 \\
\hline
\end{tabular}




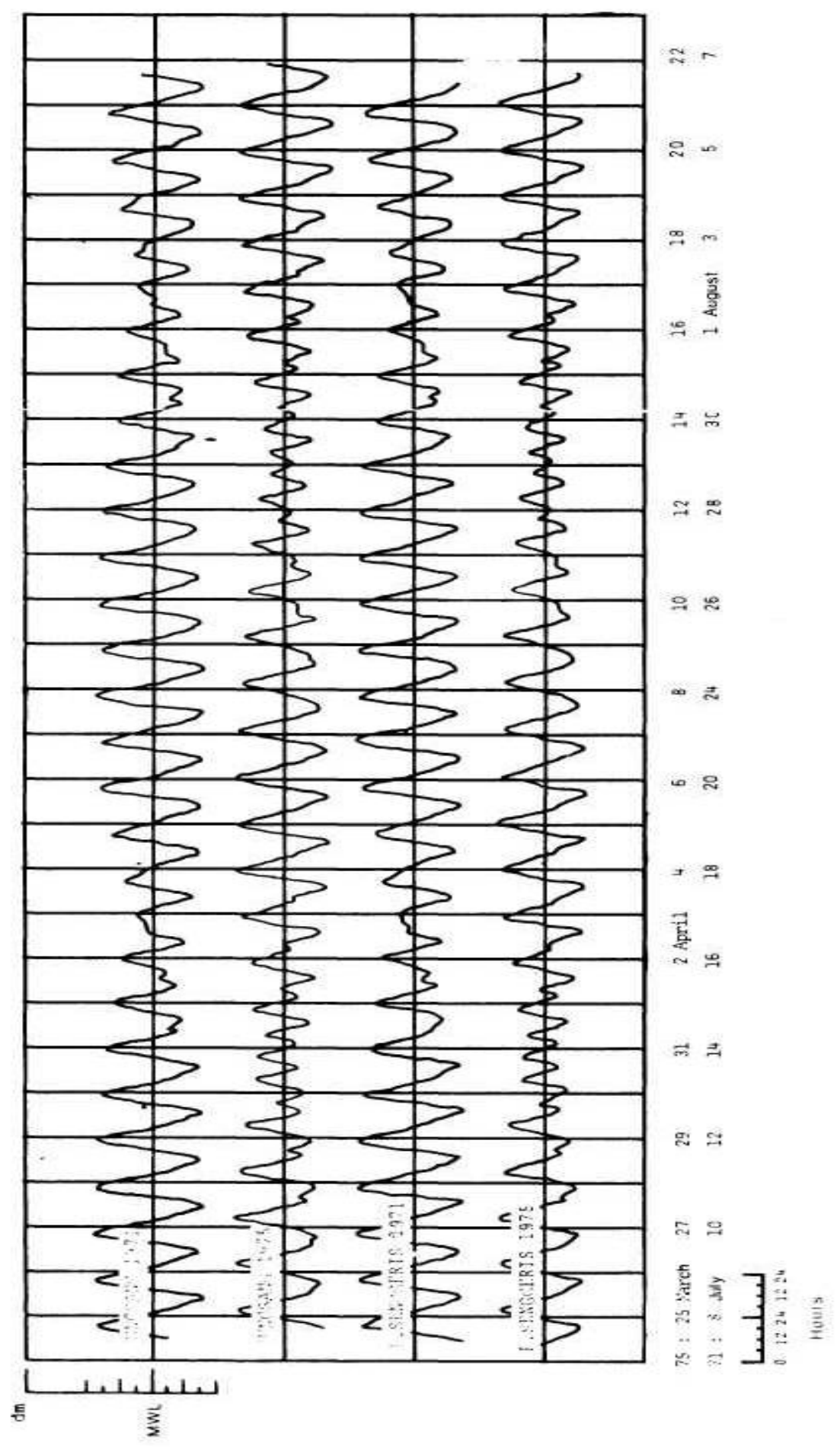

Figure 7. Tidal profiles at stations Sungsang (VII) and Pulau Senggeris (VI) during the 1971 dry season and 1975 wet season. 
TIDAL PATTERNS AND RESOURCE USE IN THE MUSI - BANYUASIN

season maximum and minimum tidal ranges are both greater than the corresponding wet season data (Table V). As shown in Figure 8, tidal propagation up the Musi occurred at a more rapid rate in 1971.

TABLE V

Comparison of tidal range at monthly maximum and minimum levels for Pulau Senggeris and Sungsang 1971 and 1975.

\begin{tabular}{llcc}
\hline Location & Tidal range & $\begin{array}{c}\text { July } \\
1971(\mathrm{~cm})\end{array}$ & $\begin{array}{c}\text { Aurch } \\
1975(\mathrm{~cm})\end{array}$ \\
\hline \multirow{2}{*}{ P. Senggeris } & maximum & 328.4 & $\mathbf{2 6 3 . 9}$ \\
& minimum & 212.9 & $\mathbf{5 8 . 9}$ \\
P. Sungsang & maximum & 342.9 & $\mathbf{2 9 1 . 9}$ \\
& minimum & 149.9 & $\mathbf{6 9 . 9}$ \\
\hline
\end{tabular}

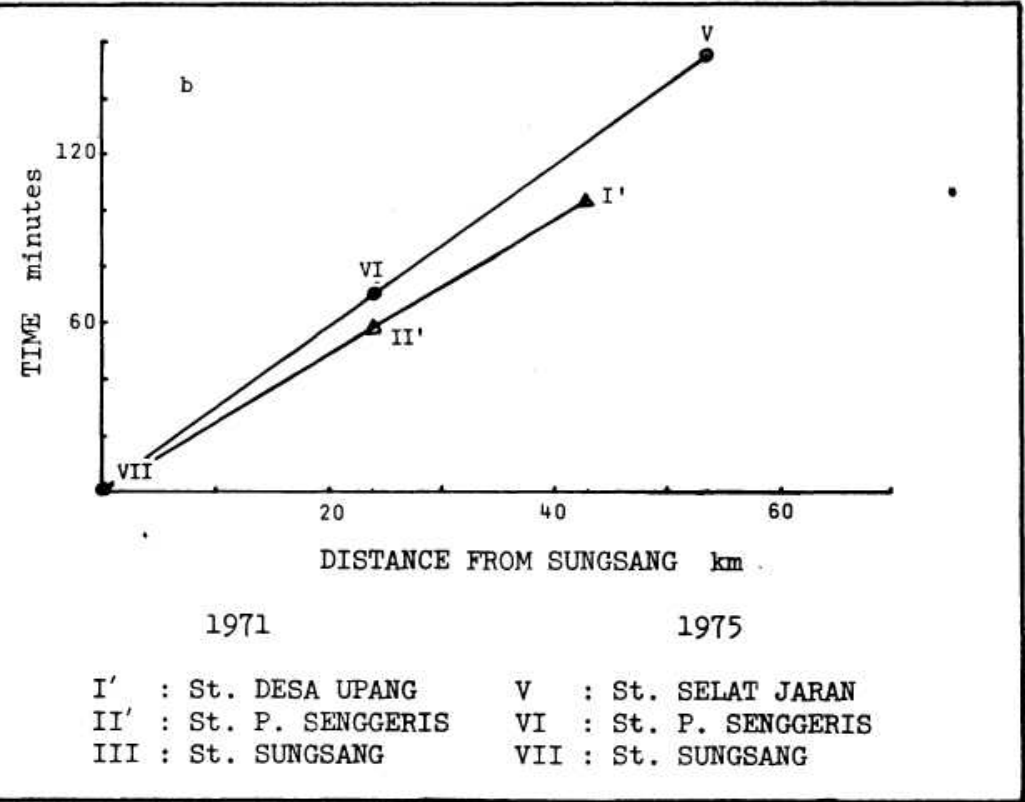

Figure 8. Time of tidal crest or trough as a function of distance up the Musi River 1971 dry season and 1975 wet season. 


\title{
SAFWAN HADI at al
}

\author{
DISCUSSION
}

\section{Tidal variation}

The tidal variations over space and time in this complex estuarine area could not be fully examined since the observation period was relatively short. However, the results suggest several conclusions and directions for future analysis and study. It is apparent that the Musi River, at similar points from the sea has significantly greater effect on reducing tidal amplitude and propagation rate than the Banyuasin. The situation in the Telang River is perhaps complicated by its multiple sources and variations in width and depth. However, this river also impedes tidal flow more than the Banyuasin. The resulting differences in time of passing of the tidal crest or trough is most striking between the Telang and Banyuasin since they are separated by a narrow delta through which the two rivers are joined by a small navigation canal $5 \mathrm{~km}$ in length. The much larger flow of water from the Musi (which has four times the watershed area of the Banyuasin) is assumed to be the major factor in accounting for these differences.

The differences in tidal patterns (as measured by the Formzahl number) between the 1971 and 1975 data for Musi River stations are undoubtedly partly an effect of seasonal differences in river flow. Other factors could be important as well. Associated with the monsoons are changes in current patterns in the Bangka Straits which will influence the balance between Indian Ocean and Pacific Ocean tidal effects (WYRTKI 1961).

The actual tidal ranges of up to $3.5 \mathrm{~m}$ are significantly different from coastal areas to the west and east. The tidal range is greater in the narrower areas of the Strait of Malacca e.g. Bagan Siapi-api $5.2 \mathrm{~m}$ (BIROWO \& UKTOLSEYA 1976) while tides of only 1 to $1.5 \mathrm{~m}$ are found along the north coast of Jawa.

\section{Relationship of tides to natural resources and their use}

\section{Coastal forest patterns}

Sediment deposition patterns are, of course, partially determined by tidal currents and the salt water they carry. Deltas form and gradually rise above the level of tidal inundation (ANDRIESSK 1974). Consequently the swamplands should be considered as a gently convex surface rising to an elevation of perhaps 10 to $15 \mathrm{~m}$ above mean sea level at some points.

Results of accurate levelling surveys are not yet available for the study area to show the relationship between land surface and tidally-influeneed water level. However, it is generally considered that only maximum range 


\section{TIDAL PATTERNS AND RESOURCE USE IN THE MUSI - BANYUASIN}

tides back up water sufficiently to flood more than the most recent deposits (which are truly intertidal). Except for the mangrove fringe the inundation is only during the wet season. Of course, throughout the year tides also act to reduce drainage of the abundant rain water from the natural forest lands.

As discussed by WATSON (1928) for mangrove and by WHITMORE (1975) for freshwater forests, the frequency and depth of inundation, and the salt content of the water zone the swampland forest into distinctive community types. As a result of the greater tidal influence and resultant salt intrusion, the mangrove forest extends much further up the Banyuasin basin, as shown in Figure 9. What is notable throughout the delta areas is the narrowness of the mangrove band. This is caused by the convex surface of the delta which effectively seals the delta interior from direct seawater flooding.

These observations have important implications in establishing forest management practises. The tidally-induced gradients severely limit the areas where various species types will grow. This holds true for both freshwater and brackishwater forms. Consequently, planning for tree farms or replanting of logged areas must take into account elevation above tides and the possibility of salt intrusion. Changing drainage patterns or allowing penetration of salt water by canal construction will influence the existing forest structure. The most important zone in this regard is the boundary area between fresh and saltwater influence. On the saltwater edge, abundant nipah (Nypa fruticans) forests and, on the freshwater edge of the zone, nibung (Oncosperma sp.) are harvested intensively for their leaves and trunk respectively.

\section{Tidal Ricefields}

The three models of tidally-influenced rice cultivation in the study area are shown in Figure 10. Local settlers cultivate land near the Musi River bank over its upper course and as far into the coastal zone as the boundary of wet season saltwater. Buginese grow rice almost to the sea using delta interior lands. The transmigrants also farm the delta interiors but not so close to the sea. Each system is an adaptation to a combination of tidal level, river flood water level, and salt intrusion. While the interactive effects of tide and river flood might be assumed to create the greatest flood hazard near the coast, this is not the case. The wet season increase in river level $90 \mathrm{~km}$ upstream is $1.1 \mathrm{~m}$, while near the sea the increase relative to sea level is very small. Thus severe flood hazard is greatest in the seasonal inland swamps. The coastal hydrological conditions stabilize rice field production, reducing hazard in both very wet and dry years compared to upland rainfed and 


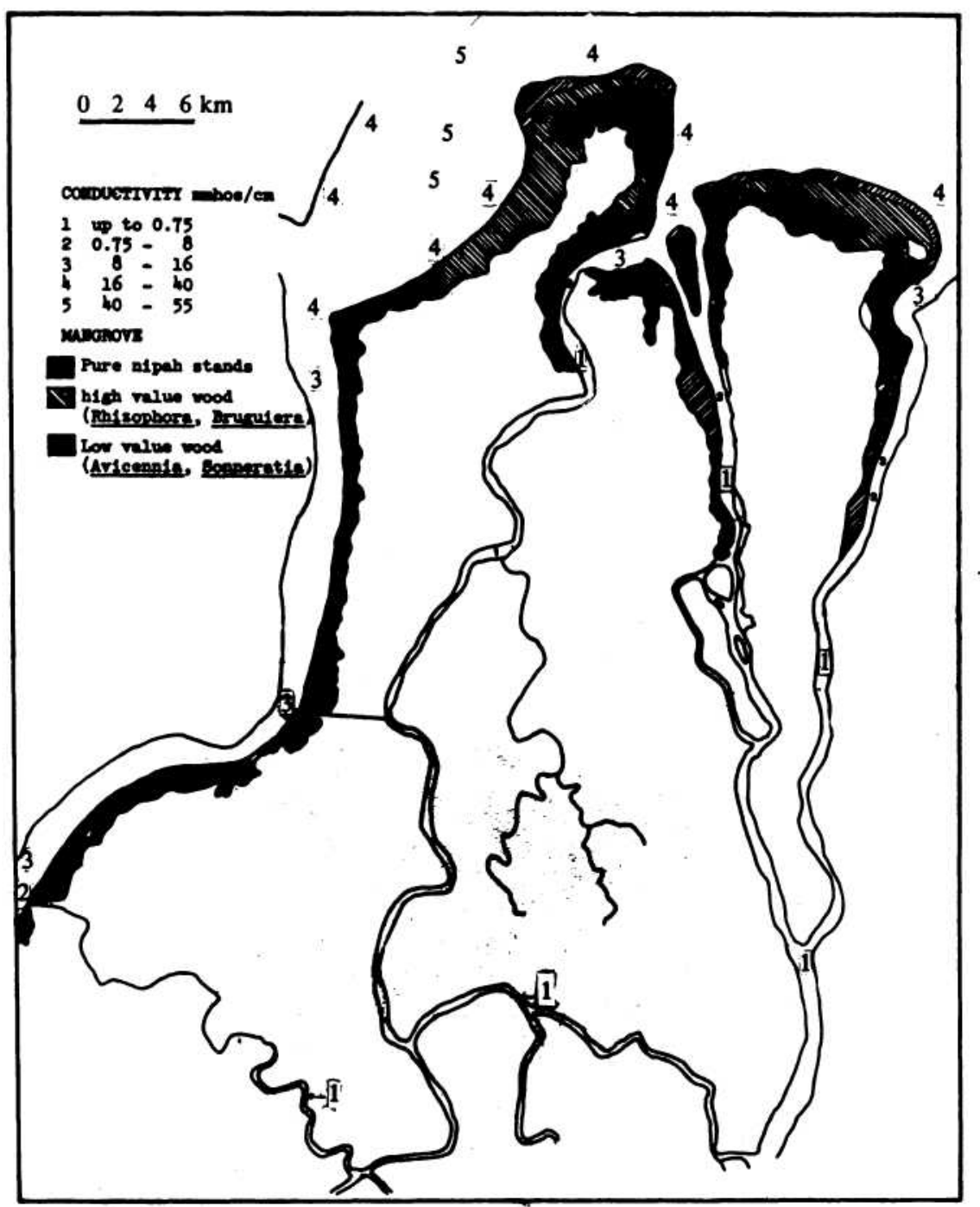

Figure 9. Distribution of mangrove forest and late wet season water conductivity. 
TIDAL PATTERNS AND RESOURCE USE IN THE MUSI - BANYUASIN

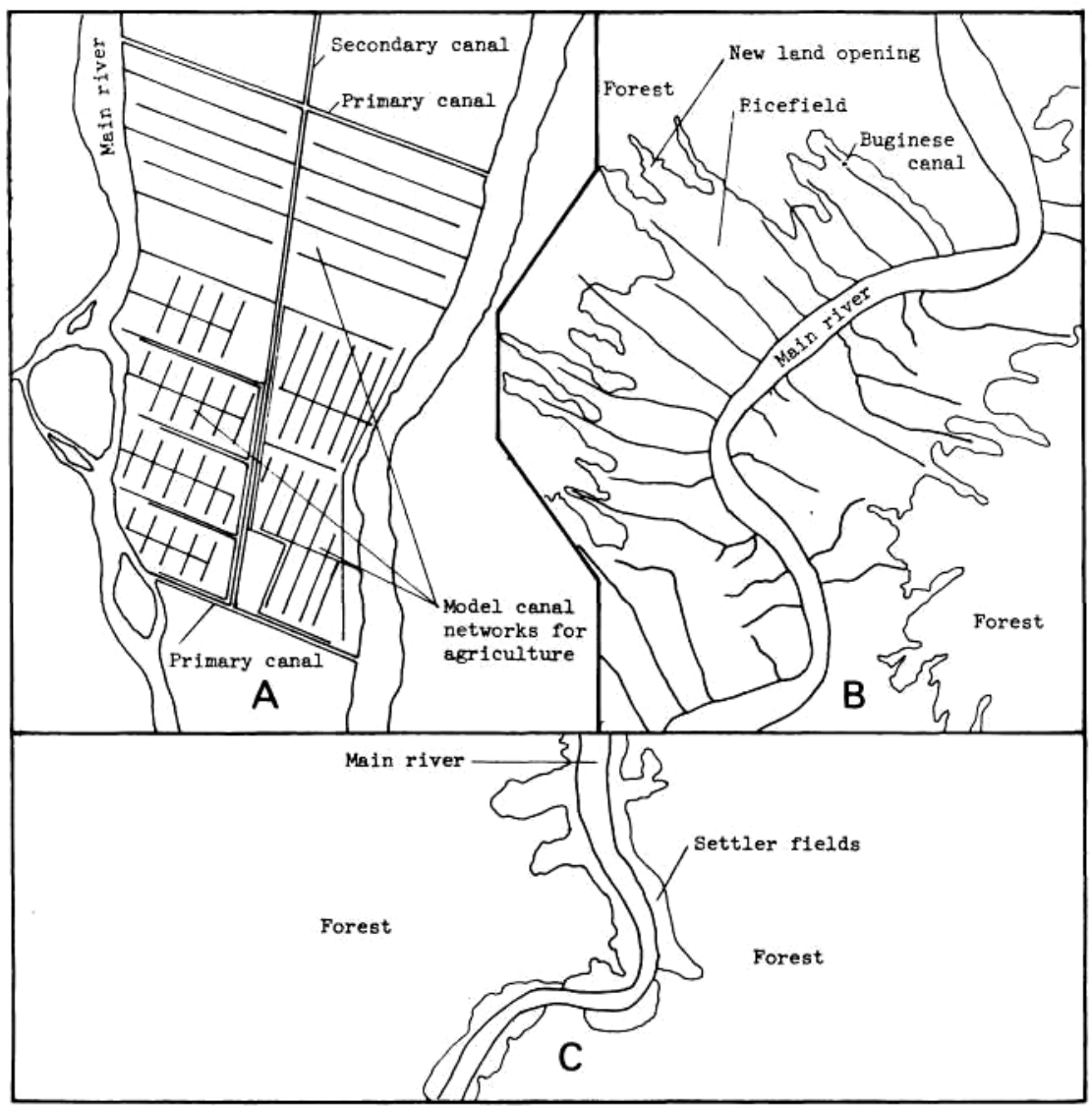

Figure 10. Three patterns of ricefield cultivation in the study area : A.

Transmigrants B. Buginese C. Local inhabitants.

"lebak" rice cultivation. Because flooding is limited to about 0.5 to $1.0 \mathrm{~m}$ it is possible to plant traditional or improved varieties of rice at the beginning of the wet season instead of waiting until flood waters are receding as is done in more inland areas. The difference between water level and field level in most situations is such that only wet season tidal back-up floods the fields. Dry season agriculture is therefore dependent on rainfall.

The most seaward Buginese ricefields are of special interest since they allow rice cultivation on lands only 2 to $3 \mathrm{~km}$ from the sea, where salt content is present year-round in the river water and where tidal range is near its maximum. Levees are low or absent and the ground is relatively flat and 


\section{SAFWAN HADI at. at.}

very close to sea level. The system works because of the slight gradient from the delta center. The Buginese construct small dead-end canals which conform to the convex land surface shape. The canals link into high salinity tidal creeks but the absence of a cross-connection to another creek or mainstem river limits tidal flushing action. Hence the canals promote drainage at low tide but the source of irrigation water is rain water, not backed-up river water. Field water levels rarely exceed $50 \mathrm{~cm}$ according to farmers.

By comparison, the government designed canal systems forming a complex network in which the tides flood and flush the entire delta with river water that is of better quality than the black swampwaters. The danger in the dry season, given the magnitude of tidal fluctuations in the open canal network, is overdrainage, with soil toxification if underlying potential acid sulphate soils are exposed to drying and oxidation. So far this has not proven to be a serious problem in Delta Upang. Dry season ground water levels are relatively high even near large canals.

The pattern of major canal construction must be adapted to the specific circumstances of salt hazard in each basin. Patterns which avoid dead-spots where debris and sediments will accumulate are, of course, desirable. It is generally considered that maximum phase and mean water level differences between canal mouths, and the width and depth of canals, will influence flow conditions. The subject is made more complex when interconnecting systems are built, as on Delta Upang, or if canal depth is constant across the delta and therefore follows the surface contours. In the study area the very different hydrological conditions of the Banyuasin and Telang Rivers present the most difficult design problems. Opening canals between these rivers is certain to present major salt intrusion hazards.

The variety of issues and available approaches raises the question of which method of tidally-influenced cultivation is best. A second question is whether the large-scale development can rely on the simple tidally-influenced canal systems, without supplemental water control structures such as tidal valves, dikes or field-level bunds. There is no easy theoretical answer to these questions. Performance monitoring and experimentation with both the Buginese and government-built systems is essential to evolve systems best suited for the long-term preservation of the fragile delta soils.

\section{Tides and Fishery Resources}

About $60 \%$ of the 2700 ton annual fish catch in the study area is taken from the estuarine waters and most of the remainder comes from the main rivers. In both cases tidal-dependent fishing gear predominates. Offshore 


\section{TIDAL PATTERNS AND RESOURCE USE IN THE MUSI - BANYUASIN}

fyke nets and large stationary filter nets ("tuguk") in the estuary or river are common. On a smaller scale, embayments along river banks are partially screened off with bamboo fences at low tide. Fish and shrimp entering during flood tide are trapped and collected during the next low tide. This system is used in both saltwater and tidally-influenced freshwater sites.

Tidal transport mechanisms are considered important in determining distribution of juvenile fish and shrimp (MACNAE 1974), while exposure to brackishwater is obligatory for some freshwater juvenile forms (especially the river prawn Macrobrachium). Hence the differences in tidal characteristics found between basins and seasonally might be expected to have significant effects on species distribution patterns. This was found to be true and to hold for canals as well. As one example, the distribution of shrimp larvae during the wet season is shown in Figure 11. Penaeus is the most restricted in location since it requires relatively high salinity at all life stages.

Perhaps the most important relationship of tides to fishery resource development is in aquaculture site planning. The elevation of brackishwater ponds relative to sea level determines frequency of filling and the expense of construction. In addition, the tidal patterns will influence larval availability as indicated above. The tidal range considered optimal for brackishwater ponds is $2.5 \mathrm{~m}$ (JAMANDRE \& RABANAL 1975). The maximum range in the study area is sufficiently close to this figure to permit development of ponds anywhere on the river banks or coast. While observed tidal variation between basins will influence the site location, other factors (bank stability, soil type, salt water content and potential for pollution) are also important. When these factors are included, the area suitable for pond culture is reduced to the zones shown in Figure 11.

The considerable extent of estuarine waters and narrow delta lands suggest possibilities for more innovative forms of tidal-dependent aquaculture. One is the use of floating cages or rafts (BARDACH et al 1972), situated in locations where the combined effect of tidal flow and river discharge will provide food and ensure sufficient water quality. The second possibility would be to develop flow-through canal networks similar to the present irrigation canals, but equipped with water control structure. The possibility of these canal systems, even in the freshwater zone influenced by tides, might be considered once the technical feasibility of culturing the very valuable Macrobrachium prawn has been tested in Indonesia. While coastal pond aquaculture has long been established in Jawa and Sulawesi, only in the northern part of Sumatra (outside the swamp zone) are there sizeable aquaculture enterprises. The conditions of swamp soil and water conditions 


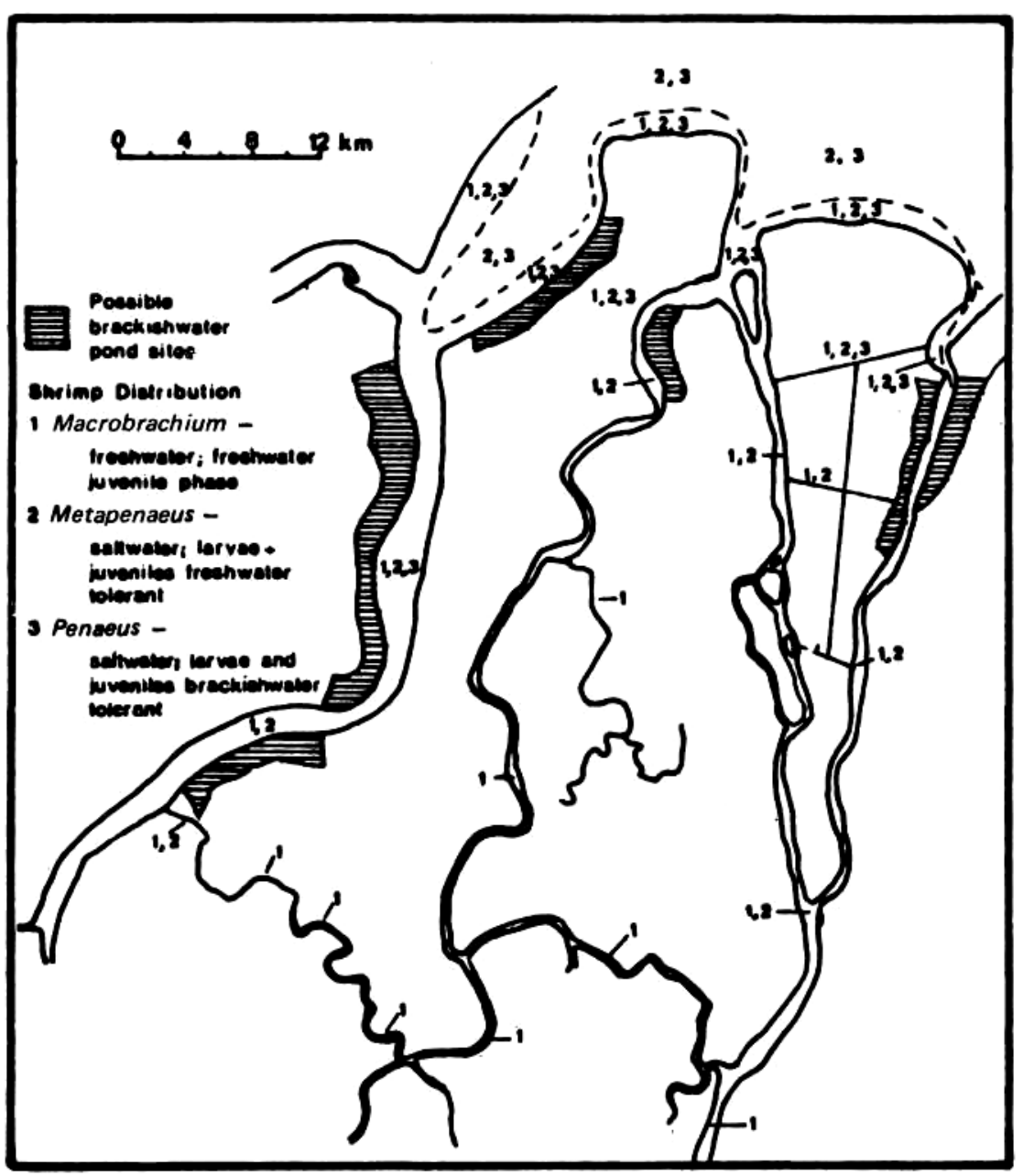

Figure 11. Shrimp larval distribution and possible sites for brackiswater pond culture.

can be major limiting conditions, suggesting a need for consideration of specialized, open water aquaculture for the swampland zone.

\section{Possible relationship to nutrient flow}

The tidal salt wedge commonly found in estuaries is assumed to be an effective mechanism for holding nutrients in the coastal zone by turbulent mixing at the salt-freshwater interphase (ODUM E.P. 1971). In the Musi 
TIDAL PATTERNS AND RESOURCE USE IN THE MUSI - BANYUASIN

River the salt wedge extends at least $20 \mathrm{~km}$ upriver in the dry season (ITB DELFT 1975). What is of special interest in the study area is the source of nutrients and organic materials flowing into this mechanism. ODUM, W. (1971) suggested that mangrove detritus is an important element in estuarine productivity. While this is likely to be the case on this coast two other sources may also be considered. One is the very sizeable input of floating aquatic weeds flushed from the upper flood plain. These weeds remain alive until they reach the slightly saline waters where they quickly die and sink. The second source is the blackwater dissolved organic compounds. These are dechelated and made available for plant growth only in the presence of saltwater (PRAKASH et al 1973).

Return of nutrients to the land through tidal flooding with brackishwater is an important hypothesis which has not been thoroughly examined. Occasional flooding, especially when the lands are not being used for crops, could act to restore nutrients. In addition the flushing with seawater would help raise soil $\mathrm{pH}$ which is generally close to the lower limit for rice cultivation. Local residents maintain that the most fertile farmlands are those just behind the nipah areas. This zone, characterized by an extreme abundance of Oncosperma sp. palm trees, would be the zone most likely to receive this nutrient input under natural conditions.

\section{Factor interactions}

The above discussion reveals the difficulty of separating three interacting factors: tidal pattern, salt intrusion, and river flood level. To these factors might be added the physiographic elements of basin form and land elevation although these are as much determined by hydrology as they are determinants of it. A synthesis of the relationship of tides to resource use is therefore very difficult unless the other factors are taken into account. The observed relationship of the three hydrological conditions to distance up the lower course of the Musi River is shown in Figure 12, along with the distribution of important natural resource uses. This diagram clarifies the relationship of tide to the other hydrological factors in a general sense. The zone of highest maximum tidal range (approximately 0 to $30 \mathrm{~km}$ from the delta front) is the zone of greatest diversity in resource use. Recalling the hypotheses of nutrient flow, it may be postulated to be the most productive coastal land and water zone as well. Therefore, in developing coastal management strategies, it should be considered a region of special ecological concern. 


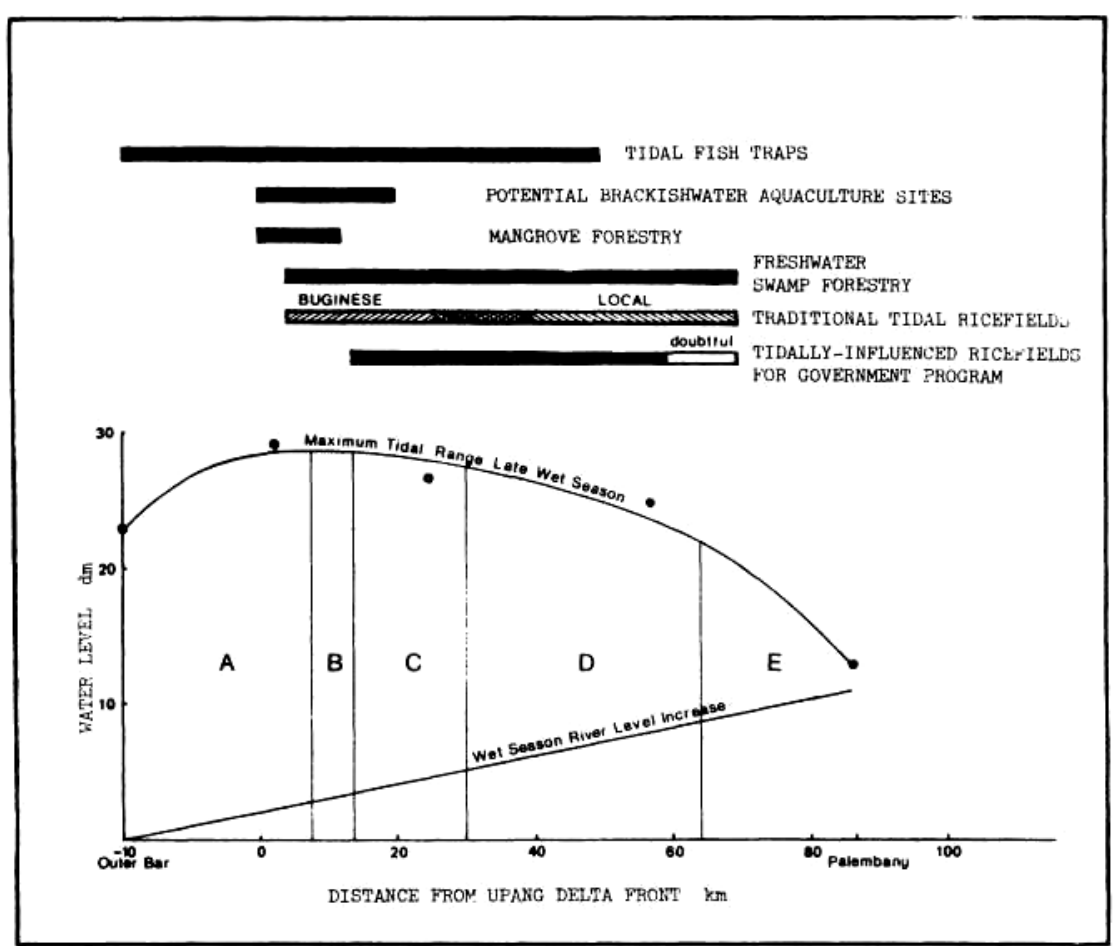

Figure 12. Wet season water level components, salts intrusion zones and resource uses along the Musi River as a function of distance from the sea. Tidal data from the present study except for the outer bar (tide table) and Palembang (observation by SUGANDAR, May 1974) points. Wet season river level increase curve from FRANKEL (1976). A to E are zones indicating the presence of salt water $(>0.5 \mathrm{mmhos} / \mathrm{cm}$ conductivity) in near-surface river water :

A. Saltwater continuously present; B. Periodically present in wet season and dry season; C. Periodically present in an average dry season; D. Periodically present in an extreme dry season; E. Salt intrusion very unlikely under any condition. The distribution of resource use activities along the river is indicated above the graph.

\section{Infrastructure changes likely to alter tidal flow}

The Musi River is likely to receive the most development attention, in both upland and lowland areas, of any basin in the southern half of Sumatra. Examination of current plans and possibilities for development suggests that tidal parameters are likely to be considerably altered over time as a result of three activities. One is the lowland agricultural canal development. Related 


\section{TIDAL PATTERNS AND RESOURCE USE IN THE MUSI - BANYUASIN}

to this is the possible upstream diversion of water out of the present basins to the vast lowlands to the southeast, or to upland agriculture sites. Secondly, in order to overcome serious shallowing of the Musi River, extensive dredging has been recommended for portions of the river between Palembang and the sea. Related to this navigation need is the suggestion of building deep water canals across Sungsang delta and a port in the Banyuasin basin (FRANKEL 1976). The third, somewhat more remote, suggestion has been to build a low dam across the Upang river to increase flow into the main Musi shipping channel for irrigation and for scouring sediments from the shipping channel.

Each of these plans would have a significant impact on tidallysupported resources and on existing infrastructure. By shifting the flocculation zone, where sedimentation occurs, or by changing the relationships of water level and tidal phase the projects may have important impacts on each other. Consequently there is a need for carefully coordinated hydrological planning which at present does not exist in this coastal zone. Ideally physical or mathematical models of the river and tidal flow in these interconnected basins are needed to accurately predict the impacts of development. As a first stage monitoring of the coastal and watershed hydrology is essential.

\section{CONCLUSIONS}

The Musi-Banyuasin coastal unit is an environment with constantly shifting hydrological zones that result in distinctive land and water subsystems of rather small dimension. The resulting balances are likely to be easily upset by the existing or potential development activities in the coastal zone or upriver areas. Because the environment is so heterogeneous the choice of adaptive options for resource use is rather broad and careful experimentation may well evolve unique solutions to this type of environment. The critical needs are a mechanism to ensure coordinated planning of infrastructure changes likely to influence hydrology or resource uses and predictive models for measuring likely impact of development on lowland hydrology.

\section{ACKNOWLEDGEMENTS}

The authors wish to thank colleagues who assisted in the tidal measurements. The techniques and programs for data analysis were devised by the late Dr. Mulia M. SidJABAT. The work was funded through projects 


\title{
SAFWAN HADI at. at.
}

\author{
of the Ministry of Public Works, Ministry of Education and a grant to \\ Institut Pertanian Bogor from the Ford Foundation.
}

\section{REFERENCES}

ALB1NSON, B. 1976. Padi area drainage and fish ponds. Symposium on Ecological Approaches to Coastal Zone Management. LON-IPB.

ANDRIESSE, J. P. 1974. Tropical lowland peats in South East Asia. Communication 63. Dept. of Agricultural Research, Royal Tropical Institute of Amsterdam: 63 pp.

BARDACH, J. E.; J. G. RYTHER and W. O. MC LARNEY 1972. Aquaculture. The farming and husbandry of fresh water and marine organisms. Wiley Interscience, New York: $868 \mathrm{pp}$.

B1ROWO, S. and H. L. UKTOLSEYA 1976. Sifat-sifat oseanografis perairan pantai Indonesia. Symposium on Ecological Approaches to Coastal Zone Management. LON-IPB.

DEFANT, A. 1961. Physical oceanography, Vol. I. Pergamon Press, Oxford: 729 pp.

ECAFE 1969. Proceedings of the second symposium on development of deltaic areas. U.N., New York. HANSEN, W. 1962. Tides, in: The Sea, Vol. I. John Wiley and Sons, New York: 764-799.

FRANKEL, E. C. 1976. Palembang port study. U.S.A.I.D./Ministry of Communication, Government of Indonesia.

ITB - DELFT 1975. Laporan cooperative study on tidal engineering. LAPI - Institut Teknologi Bandung.

JAM ANDRE, T. J., JR. and H. R. RABANAL 1975. Engineering aspects of brackishwater aquaculture in the South China Sea region. South China Sea Fisheries Development and Coordinating Programme. Manila, Philippines.

MACHNAE, W. 1974. Mangrove forests and fisheries. Indian Ocean Programme. IOFC/DEV/74. FAO, Rome: $35 \mathrm{pp}$.

MINISTRY OF PUBLIC WORKS 1971. Prefeasibility report on Upang area tidal land reclamation project.

MOLINA, M. G. 1974. Hydrometeorological analysis and evaluation of land and water resources development in South East Sumatra, Indonesia. UNDP - FAO.

MUNK, W. H. and D. E. CARTWRIGHT 1966. Tidal spectroscopy and prediction. Phil. Trans. Roy. Soc. London A, 259:533-581.

ODUM, E. P. 1971. Fundamentals of ecology. W.B. Saunders Co., Philadelphia: 374 pp.

ODUM, W. E. 1971. Pathways of energy flow in a South Florida estuary. Univ. of Miami Sea Grant Tech. Bull. 7:162 pp.

PONS, L. J. and I. S. ZONNELVELD 1965. Soil ripening and soil classification. Initial soil formation in alluvial deposit and a classification of the resulting soils. ILRI Bull. Wageningen, The Netherlands. $128 \mathrm{pp}$.

PRAKASH, A. et al. 1973. Influence of humic substances on the growth of marine phytoplankton diatoms. Limnology and Oceanography 18(4):516-524.

SCHUSTER, W. H. 1952. Fish culture in brackish-water ponds of Java. Indo-Pacific Fisheries Council. Special Publication, No. 1:143 pp. 


\section{TIDAL PATTERNS AND RESOURCE USE IN THE MUSI - BANYUASIN}

SIOJABAT, M. M. 1971. Laporan penelitian tidal waves studies. Distribusi karakteristik pasang surut di dacrah Upang, Sumatra Sclatan. Ministry of Public Works - Institut Pertanian Bogor, Bogor.

SUGANDAK, S. 1975. Komputasi pasut satu dimensi. LAPI-ITB.

TEAM SUKVE1 EKOLOG1 IPB 1975. Draft laporan akhir survei ekologi Delta Upang-Banyuasin I. Ministry of Public Works - Institut Pertanian Bogor, Bogor.

VAN W1JK, C. L. 1951. Soil survey on the tidal swamps of South Borneo in connection with the agricultural possibilities. Contr. of the Gen. Agr. Res. Stat. Bogor, Indonesia No. 123:49 pp.

WATSON, J. G. 1928. Mangrove forests of the Malay Peninsula. Malayan Forest Records, No. 6:275 pp.

WHITMORK, T. C. 1975. Tropical rain forests ofthe Far East. Clarendon Press, Oxford: 282 pp.

WYKTKI, K. 1961. Physical oceanography of South East Asian waters. Naga Reports 2. The University of California. Scripps Institute of Oceanography, La Jolla, California: 196 pp.

ZETTLER, B. D. and R. A. CUMM1NG 1967. A harmonic method for predicting shallow water tides. Jour. Mar. Sci. 25:103-113. 